\title{
Categories of Resistance to Greenbug and Yellow Sugarcane Aphid (Hemiptera: Aphididae) in Three Tetraploid Switchgrass Populations
}

\author{
Kyle G. Koch • Jeffrey D. Bradshaw • \\ Tiffany M. Heng-Moss • Gautam Sarath
}

Published online: 1 February 2014

(C) The Author(s) 2014. This article is published with open access at Springerlink.com

\begin{abstract}
Switchgrass, Panicum virgatum L., has been targeted as a bioenergy feedstock. However, little is currently known of the mechanisms of insect resistance in this species. Here, two no-choice studies were performed to determine the categories (antibiosis and tolerance) and relative levels of resistance of three switchgrass populations (Kanlow-lowland ecotype, Summer-upland ecotype, and third generation derivatives between Kanlow $\times$ Summer plants, $\mathrm{K} \times \mathrm{S}$ ) previously identified with differential levels of resistance to the greenbug, Schizaphis graminum (Rondani), and yellow sugarcane aphid, Sipha flava (Forbes). No-choice studies indicated that Kanlow possessed multi-species resistance, with high levels of antibiosis to both aphid species, based on aphid survival at 7 and 14 days after aphid introduction and cumulative aphid days, while $\mathrm{K} \times \mathrm{S}$ possessed low-to-moderate levels of antibiosis to $S$. flava. Further, functional plant loss indices based on plant height and biomass indicated that tolerance is an important category of resistance for Summer plants to S. graminum. These studies also indicated that Summer lacks both tolerance and antibiosis to $S$. flava, relative to the other switchgrasses tested, whereas $\mathrm{K} \times \mathrm{S}$ lack tolerance and antibiosis to $S$. graminum. These studies are the first attempt to analyze the categories of resistance in switchgrass and provide critical information for characterizing the biological mechanisms of
\end{abstract}

K. G. Koch · T. M. Heng-Moss

Department of Entomology, University of Nebraska, Lincoln, NE 68583, USA

J. D. Bradshaw $(\bowtie)$

Department of Entomology, Panhandle Research and Extension Center, University of Nebraska, Scottsbluff, NE 69361, USA

e-mail: jbradshaw2@unl.edu

G. Sarath

USDA-ARS, Grain, Forage and Bioenergy Research Unit, Lincoln, NE 68583, USA resistance and improving our knowledge of the plant-insect interactions within this system.

Keywords Aphids $\cdot$ Switchgrass $\cdot$ Panicum virgatum $\mathrm{L}$. Sipha flava $\cdot$ Schizaphis graminum $\cdot$ Plant resistance

\section{Introduction}

Switchgrass, Panicum virgatum L., a perennial warm-season grass native to the tallgrass prairie regions of North America, east of the Rocky Mountains, is being developed as a bioenergy crop for marginal soils in the USA [32, 40]. It is a polyploid species, with a range of ploidies [7], however the tetraploid switchgrasses, which occur as upland or lowland ecotypes possess the best yield attributes [18, 40, 43]. In addition, hybrids between certain upland and lowland tetraploid populations display heterosis for biomass yields [20].

While switchgrass has received increased agronomic attention, it is likely that large-scale plantings of this species will result in insect infestations that could negatively impact establishment and yields. As an example, in the related native warm-season perennial, buffalograss, Buchloë dactyloides (Nuttall) Engelmann, an emergence in multiple important pests was demonstrated with increased use of this species as a turfgrass $[4,16]$. Likewise, recent work has demonstrated that insect problems may occur, particularly as production increases [1, 9, 22, 28]. In 2004, a poorly understood species, Blastobasis repartella (Dietz), was rediscovered, and appears to be a monophagous stem-borer restricted to switchgrass [1, 28]. Four additional lepidopterans, Spodoptera frugiperda (J.E. Smith) [9, 10, 24, 30], Mythimna unipuncta (Haworth) [29], Papaipema nebris (Guenée), and Haimbachia albescens Capps [31] have also been recently documented on various populations of switchgrass. Burd et al. [6] demonstrated that multiple switchgrass populations are suitable hosts to several 
important cereal aphids including: Schizaphis graminum (Rondani) (greenbug), Rhopalosiphum padi (L.) (bird-cherry oat aphid), Rhopalosiphum maidis (Fitch) (corn leaf aphid), and Sipha flava (Forbes) (yellow sugarcane aphid). Additionally, other important insect pests have been more incidentally documented in association with switchgrass, including grasshoppers (Acrididae) [27, 38]. As a result, the prevalence of those and other potential pests in switchgrass may increase as the agricultural landscape changes to accommodate increased production of bioenergy feedstocks $[5,22]$.

One of the most effective and sustainable strategies for controlling insect pests has been the development of insect-resistant plants. According to Smith [34, 35], hundreds of insect-resistant cultivars are currently grown in the USA, offering substantial economic and environmental benefits. Insect-resistant plants provide an attractive pest management strategy by reducing insecticide application, resulting in the reduction of input costs and harsh chemicals in the environment. Further, plant resistance may improve the efficiency of insect biological control agents, synergizing the interactions between the insectresistant plants and natural enemies by decreasing the vigor of the insect pest [34, 35]. Dowd and Johnson [9] noted that the apparent lack of insect pest problems in switchgrass suggested that insect resistance genes are present. Differential resistance has been documented among switchgrass populations to potential insect pests including, S. frugiperda [9, 10], as well as S. flava and $S$. graminum [19]. Further, Dowd et al. [10] were able show that multiple resistance mechanisms may be at work; however, the categories and relative levels of resistance being expressed among these populations have remained undocumented.

Antibiosis, antixenosis, and tolerance are important categories of resistance and have all been used as tactics for integrated pest management. Insect-resistant switchgrasses may effectively contribute to pest management strategies by negatively affecting the pest insect's biology (antibiosis), behavior (antixenosis), and/or by tolerating or repairing (tolerance) the injury resulting from the insect pest. Identifying these categories is critical for characterizing the biological mechanisms of resistance and improving our knowledge of the plant-insect interactions within this system. The objective of this research was to characterize the categories (antibiosis and tolerance) and relative levels of antibiosis and tolerance of selected tetraploid switchgrass populations to two potential aphid pests (S. flava and S. graminum).

\section{Materials and Methods}

Plant Material Two no-choice studies were performed to evaluate the categories and relative levels of antibiosis and tolerance of three switchgrass populations: Kanlow (lowland cultivar), Summer (upland cultivar) [3, 39], and a third generation stabilized population of plants, hereafter referred to as $\mathrm{K} \times \mathrm{S}$, originally derived by intermating Kanlow (male) and Summer (female) plants to produce hybrids [20,39]. Seeds for all populations were provided by Dr. Kenneth Vogel (USDA-ARS, Grain, Forage, and Bioenergy Research Unit, Lincoln, Nebraska).

Plants were grown to the V-1 stage [23] in Cone-tainers essentially as described earlier [19]. Each Cone-tainer had a single plant. Cone-tainers were placed in 7 by 14 cone-tainer trays and maintained in a greenhouse at $25 \pm 7{ }^{\circ} \mathrm{C}$ with the lighting augmented by $400-\mathrm{W}$ Metal Halide lamps to produce a photoperiod of 16:8 (L:D) hours. After emergence, plants were thinned down to one plant per cone-tainer. Plants were fertilized every 2 weeks with a soluble (20:10:20 N/P/K) fertilizer.

Insect Colonies The switchgrasses were evaluated for the categories of resistance to $S$. flava and S. graminum (biotype I). Aphid colonies were obtained from Dr. John D. Burd, USDA-ARS in Stillwater, Oklahoma. The S. flava colony was maintained on a continuous supply of 'Haxby' barley plants, while $S$. graminum was maintained on a susceptible sorghum cultivar 'BCK60'. Both colonies were maintained in the greenhouse at $25 \pm 7{ }^{\circ} \mathrm{C}$ and $16: 8(\mathrm{~L} / \mathrm{D})$ hours within clear plastic cages, approximately $12.5 \mathrm{~cm}$ diameter and ventilated with organdy fabric. Attempts were made to condition aphids on the same switchgrass population and developmental stage they were to be tested on for at least 1 week; however, efforts to condition enough of either aphid species on Kanlow were unsuccessful. As a result, all aphids were conditioned for at least 1 week prior to the beginning of each study on Summer, which had preliminarily been identified as the susceptible population [19], in the V-1 stage.

Category Studies Two non-choice studies were performed to identify the presence of antibiosis and/or tolerance in three switchgrass populations (Summer, Kanlow, and $\mathrm{K} \times \mathrm{S}$ ) to $S$. graminum, biotype I (study 1) and S. flava (study 2). In each study, the susceptible sorghum BCK60, was included as a control (in a similar developmental stage), to provide a wellknown standard for both aphids. The experimental design for both studies was a completely randomized design with a 3 by 4 factorial (three levels of aphid infestation and three switchgrass populations, plus sorghum) and ten replications. At the onset of both experiments, plants within a population were placed into groups of three according to similar height and quality. Plants within the group were then randomly assigned an infestation level of 0,5 , or 10 aphids. This provided an uninfested control (0), a low infest level (5), and a high infest level (10). The corresponding number of apterous, adult aphids was transferred to each plant with a fine paintbrush and then caged with tubular plastic cages $(4 \mathrm{~cm}$ diameter by $46 \mathrm{~cm}$ height) with vents covered with organdy fabric to 
confine the aphids. After aphid introduction, plants were maintained in a greenhouse at $25 \pm 7^{\circ} \mathrm{C}$ and 16:8 (L/D) hours.

Tolerance Evaluation Plants were rated for aphid damage twice a week by using a visual damage rating on a 1-5 scale. Damage ratings served as a visual assessment of the injury sustained by the plant from aphid feeding [37]. The damage rating scale was adopted from Heng-Moss et al. [16], where $1=10 \%$ or less of the leaf area damaged; $2=11-30 \%$ of the leaf area damaged; $3=31-50 \%$ of the leaf area damaged; $4=$ $51-70 \%$ of the leaf area damaged; and $5=71 \%$ or more of the leaf area damaged and the plant near death. Plant damage was characterized by chlorosis, a reddish discoloration, or desiccation of the leaf. Experiments were terminated 21 days after initial aphid introduction, at which point, mean damage ratings had reached 4 for a given population, or aphid numbers and damage ratings plateaued across all populations of switchgrass. Plant heights and dry weights were then determined at the conclusion of each experiment. Plant biomasses were determined after placing the plant material in an oven $60{ }^{\circ} \mathrm{C}$ for 1 week.

Aphid damage ratings, plant heights, and biomasses were used to calculate two functional plant loss indices (FPLIs) [17, $26,37,42]$ to assess the relative levels of tolerance among the selected switchgrass populations. The FPLIs were calculated using the following formulae:

$$
\begin{aligned}
& \operatorname{FPLI}_{\text {(biomass) }}=1-\left(\frac{\text { biomass of infested plant }}{\text { biomass of control plant }}\right) \times\left(1-\frac{\text { damage rating }}{5}\right) \times 100 \\
& \operatorname{FPLI}_{(\text {height }}=1-\left(\frac{\text { height of infested plant }}{\text { height of control plant }}\right) \times\left(1-\frac{\text { damage rating }}{5}\right) \times 100
\end{aligned}
$$

In both FPLIs, lower values indicate the presence of tolerance, while higher values indicate a lack of tolerance.

Antibiosis Evaluation The same plants used in the tolerance studies were also evaluated for the antibiosis experiment. To assess antibiosis, aphids were introduced to the plants at two infestation levels (5 and 10) and confined (as described above). To evaluate the plants' effect on aphid fecundity and survival, aphids were counted on each plant 7 and 14 days after aphid introduction. Because aphid counts at a given time only provide a single point in time, the plants' effects on aphid multiplication over time were also evaluated by performing aphid counts twice a week (during evaluations for plant damage) for the duration of the experiment and calculating cumulative aphid days (CAD) using the following formula: $\mathrm{CAD}=\sum_{i=1}^{n}\left(\frac{N_{i}+N_{i+1}}{2}\right) \times T$, where $N_{i}$ is the total number of aphids on a plant at a given evaluation date $i, N_{i+1}$ is the total number of aphids on the same plant on the subsequent evaluation date, and $T$ is the number of days between the two evaluation dates [14]. As described above, evaluations were performed for 21 days.

Statistical Analysis Generalized linear mixed model analyses (PROC GLIMMIX, [33]) were conducted for each functional plant loss index to detect population differences in switchgrass tolerance to aphid feeding. For the antibiosis evaluations, the mean number of aphids at 7 and 14 days after infestation was analyzed as a repeated measures design using generalized linear mixed model analyses (PROC GLIMMIX). Cumulative aphid days, used to detect the effect that each population of switchgrass had on aphids over time, was analyzed using generalized linear mixed model analyses (PROC GLIMMIX) after a square root transformation of the data to meet the assumptions of the generalized linear mixed model analysis. Where appropriate, means were separated using Fisher's least significant difference (LSD) procedure $(\alpha=0.05)$. An experimental unit was an individual plant.

\section{Results}

\section{Tolerance Studies}

Tolerance Study S. graminum Statistically significant differences were detected among the grasses for the FPLI index based on plant biomass with $S$. graminum, for both infestation levels (Fig. 1; five aphids: $F=8.13$; $\mathrm{df}=3,72 ; P<0.0001$; ten aphids: $F=8.53$; $\mathrm{df}=3,72 ; P<0.0001)$. The FPLI based on plant biomass was highest for the susceptible sorghum check at both infestation levels; however, $\mathrm{K} \times \mathrm{S}$ was not significantly different from sorghum at either the 5- or 10-aphid infestation level. Summer had significantly lower FPLI values at both infestation levels than sorghum, as well as $\mathrm{K} \times \mathrm{S}$ at the higher infestation level. Kanlow had significantly lower FPLI values than any of the other grass treatments; however, as demonstrated by the results for antibiosis, that can likely be attributed to its strong antibiotic response. Thus, FPLI values for Kanlow were deemed to be skewed, and are not presented. 
Fig. 1 FPLI values for S. graminum evaluations based on plant biomass (5- and 10-aphid infestation levels). Bars with the same letter within an initial infestation level are not significantly different $(P>0.05)$, LSD test. Lower FPLI value indicates tolerance

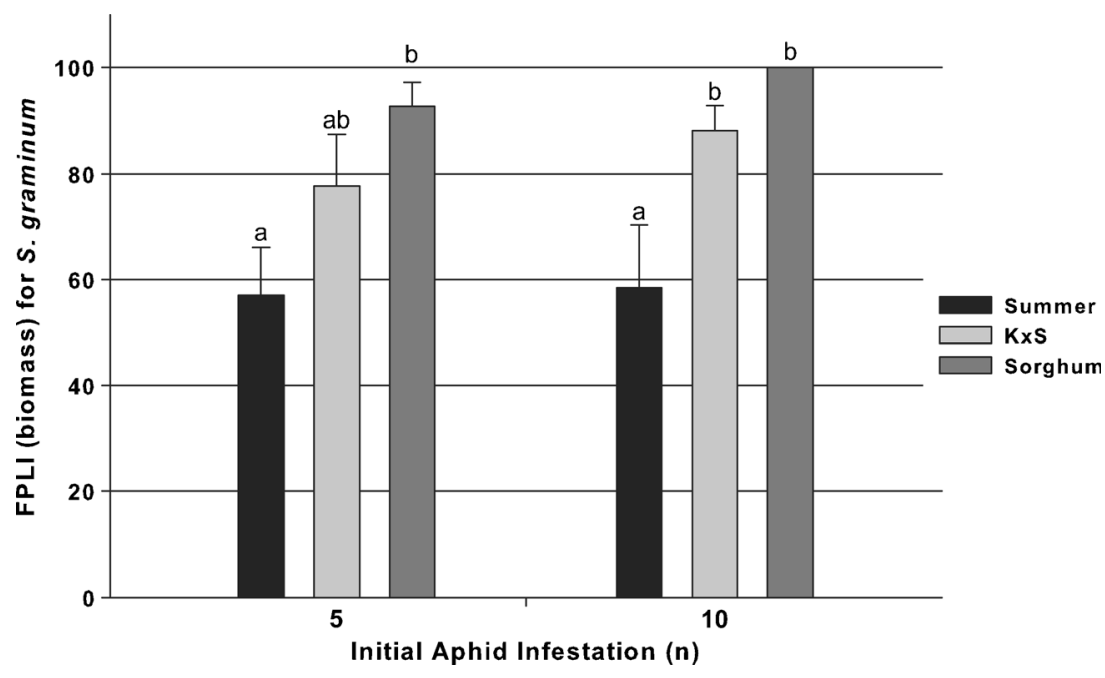

Significant differences in the FPLI index based on plant height were also detected among the grasses evaluated for the two $S$. graminum infestation levels (Fig. 2; five aphids: $F=$ $6.65 ; \mathrm{df}=2,54 ; P<0.003$; ten aphids: $F=7.88 ; \mathrm{df}=2,54 ; P=$ $0.001)$. Similar to the FPLIs for biomass, FPLI values based on plant height were highest for the susceptible sorghum check and $\mathrm{K} \times \mathrm{S}$, with no significant differences detected between sorghum and $\mathrm{K} \times \mathrm{S}$ at either infestation level. Summer had significantly lower FPLI values at both infestation levels than sorghum and $\mathrm{K} \times \mathrm{S}$. Collectively, the FPLI values based on plant biomass and plant height indicate the presence of tolerance in Summer to S. graminum.

Tolerance Study S. flava Significant differences in the FPLI index based on plant biomass for $S$. flava were also detected among grasses for both levels of infestation (Fig. 3; five aphids: $F=9.80 ; \mathrm{df}=3,71 ; P<0.0001$; ten aphids: $F=12.09$; $\mathrm{df}=3,71 ; P<0.0001)$. The susceptible sorghum had the highest FPLI values for $S$. flava at both infestation levels. The FPLI values for Summer were not significantly different from sorghum at either infestation level, indicating a lack of tolerance. The mean FPLI value for $\mathrm{K} \times \mathrm{S}$ at the 5 -aphid infestation level was significantly lower than both Summer and sorghum. For the 10-aphid infestation level, the FPLI value for $\mathrm{K} \times \mathrm{S}$ was significantly lower than sorghum; however, it was not significantly different from Summer. Again, Kanlow had the lowest FPLI values among grasses; however, it is not presented since the low FPLI values were considered to be a product of its strong antibiotic effect.

Significant differences in the FPLI based on plant height were also detected among treatments for both $S$. flava infestation levels (Fig. 4; five aphids: $F=16.59$; $\mathrm{df}=3,72 ; P<0.0001$; ten aphids: $F=21.40$; $\mathrm{df}=3,72 ; P<0.0001)$. At the 5-aphid infestation level, sorghum had a mean FPLI value significantly higher than both Summer and $\mathrm{K} \times \mathrm{S}$. However, the mean FPLI was significantly lower for $\mathrm{K} \times \mathrm{S}$ than Summer at the lower infestation level. Sorghum also produced the highest FPLI value at the 10-aphid infestation level; however, it was not significantly different from Summer at that infestation level. No significant difference was detected between $\mathrm{K} \times \mathrm{S}$
Fig. 2 FPLI values for S. graminum evaluations based on plant height (5- and 10-aphid infestation levels). Bars with the same letter within an initial infestation level are not significantly different $(P>0.05)$, LSD test. Lower FPLI value indicates tolerance

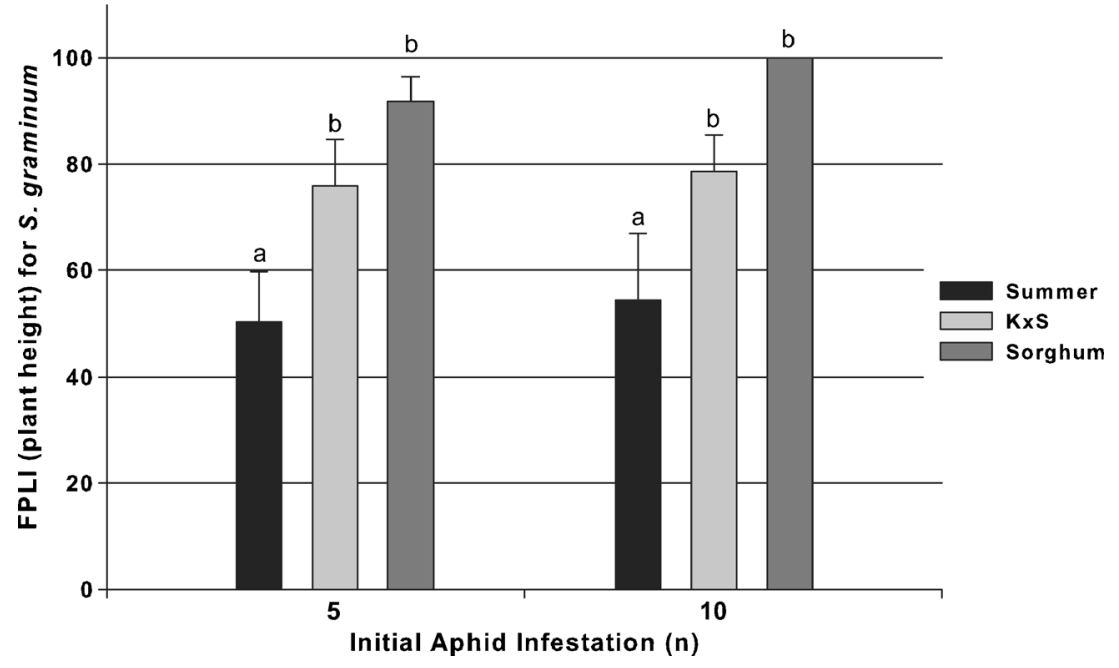


Fig. 3 FPLI values for S. flava evaluations based on plant biomass (5- and 10-aphid infestation levels). Bars with the same letter within an initial infestation level are not significantly different $(P>0.05)$, LSD test. Lower FPLI value indicates tolerance

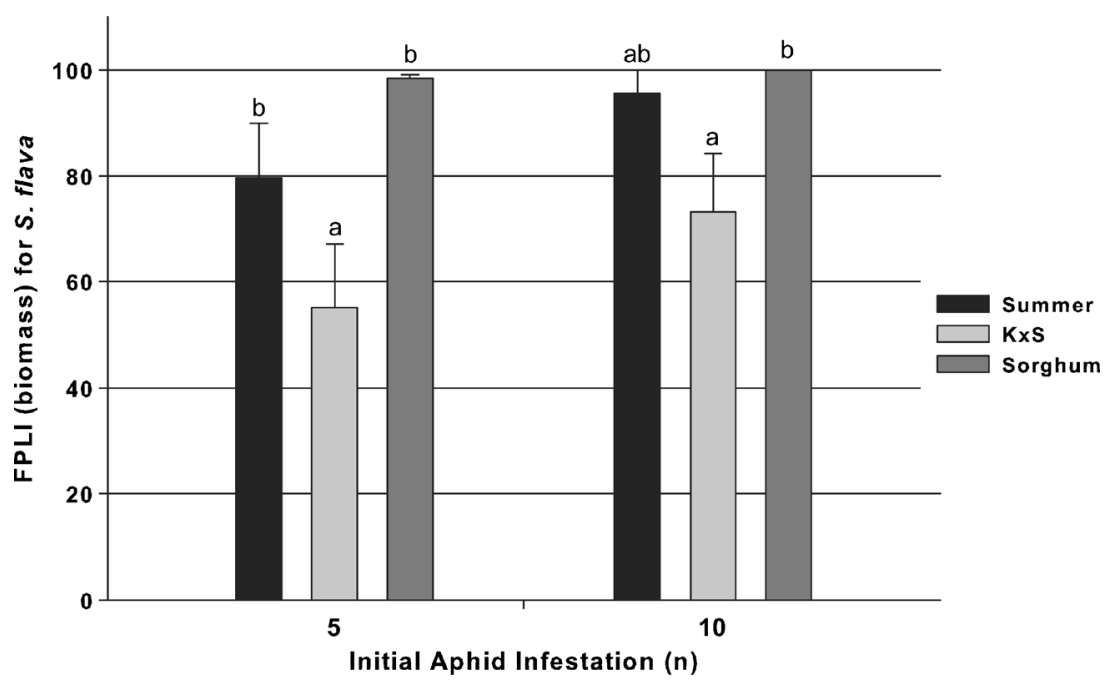

and Summer for FPLI at the high infestation level, however the FPLI value for $\mathrm{K} \times \mathrm{S}$ was significantly lower than sorghum.

\section{Antibiosis Studies}

Antibiosis Study S. graminum Significant differences were detected among the three switchgrass populations and sorghum for the mean number of $S$. graminum at both infestation levels (Table 1; five aphids: $F=12.23$; $\mathrm{df}=3,72 ; P<0.0001$; ten aphids: $F=7.05 ; \mathrm{df}=3,72 ; P=0.0003)$. The susceptible sorghum cultivar BCK60, included in this evaluation as a check, consistently had the highest mean number of $S$. graminum among the grasses tested at all time points and infestation combinations. However, at the 14-day and 10aphid infestation level, no significant differences were detected among any of the switchgrasses and sorghum for mean aphid numbers, despite sorghum supporting at least twice as many aphids as any switchgrass population. This was likely the result of the large variation among replications for that treatment combination. Also, aphid counts were generally skewed among the susceptible grasses within the 14-day 10aphid infestation level due to aphid populations overwhelming the susceptible plants, resulting in the reduction of plant quality and subsequent decline in aphid numbers. Thus, that treatment combination was found to be less informative than others.

At the 7-day time point and 5-aphid infestation level, $\mathrm{K} \times \mathrm{S}$ was not significantly different from the susceptible sorghum, with mean aphid numbers ( \pm SEM) of $34.2 \pm 5.2$ and $45.2 \pm 4.6$, respectively. Further, $\mathrm{K} \times \mathrm{S}$ consistently supported the most $S$. graminum among the three switchgrass populations tested at all treatment combinations, and had significantly more aphids than both Kanlow and Summer at both 7 and 14 days for the 5-aphid infestation level. The mean S. graminum $( \pm$ SEM) for $\mathrm{K} \times \mathrm{S}$ was $38.3 \pm 7.6$ at the 7 -day 10 -aphid infestation level; however, it did not support aphid numbers that were
Fig. 4 FPLI values for $S$. flava evaluations based on plant height (5- and 10-aphid infestation levels). Bars with the same letter within an initial infestation level are not significantly different $(P>0.05)$, LSD test. Lower FPLI value indicates tolerance

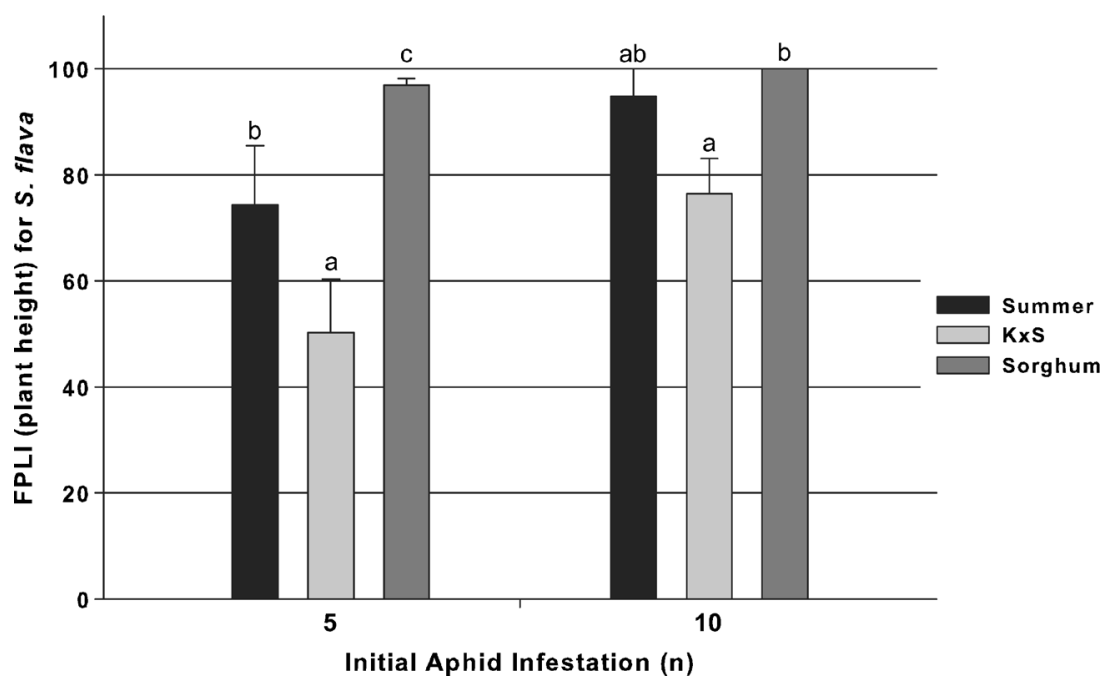


Table 1 Mean $\pm \mathrm{SEM}^{\mathrm{a}}$ number of $S$. graminum among switchgrass populations and sorghum at 7 and 14 days after initial introduction of five or ten aphids

Mean \pm SEM S. graminum

\begin{tabular}{|c|c|c|c|c|}
\hline \multirow[b]{2}{*}{ Switchgrass population } & \multicolumn{2}{|c|}{7 days after aphid introduction } & \multicolumn{2}{|c|}{14 days after aphid introduction } \\
\hline & 5-aphid infestation level & 10-aphid infestation level & 5-aphid infestation level & 10-aphid infestation level \\
\hline Kanlow & $7.3 \pm 3.6 \mathrm{a}$ & $8.2 \pm 1.8 \mathrm{a}$ & $4.4 \pm 2.5 \mathrm{a}$ & $1.3 \pm 0.7 \mathrm{a}$ \\
\hline Summer & $18.5 \pm 3.8 \mathrm{~b}$ & $28.5 \pm 6.8 b$ & $10.0 \pm 3.9 \mathrm{a}$ & $14.7 \pm 6.8 \mathrm{a}$ \\
\hline $\mathrm{K} \times \mathrm{S}$ & $34.2 \pm 5.2 \mathrm{c}$ & $38.3 \pm 7.6 \mathrm{~b}$ & $51.8 \pm 24.3 b$ & $23.4 \pm 9.1 \mathrm{a}$ \\
\hline Sorghum & $45.2 \pm 4.6 \mathrm{c}$ & $86.7 \pm 8.4 \mathrm{c}$ & $137.7 \pm 25.7 \mathrm{c}$ & $56.5 \pm 33.2 \mathrm{a}$ \\
\hline
\end{tabular}

${ }^{a}$ Treatment means within the same column followed by the same letter indicate no significant differences $(P>0.05)$, LSD test

significantly higher than Summer, which had $28.5 \pm 6.8$ aphids.

The mean number of $S$. graminum among switchgrass populations was consistently the lowest for Kanlow at all treatment combinations. Kanlow supported significantly fewer aphids than Summer and $\mathrm{K} \times \mathrm{S}$ within both the 5-aphid and 10 -aphid infestation levels at the 7-day evaluation, with mean aphid numbers ( \pm SEM) of $7.3 \pm 3.6$ and $8.2 \pm 1.8$, respectively. Kanlow also had significantly fewer aphids than $\mathrm{K} \times \mathrm{S}$ at the 14-day 5-aphid infestation level, with mean aphid numbers ( \pm SEM) of $4.4 \pm 2.5$ and $51.8 \pm 24.3$, respectively, for the two populations. Although no significant differences were detected among any of the grasses at the 14-day 10-aphid infestation level, Kanlow supported a mean aphid number $( \pm$ SEM) of 1.3 \pm 0.7 ; less than one-tenth of the aphids supported by the next lowest population, Summer, with $14.7 \pm 6.8$ mean aphids.

Antibiosis Study S. flava Significant differences were also detected among switchgrass populations and sorghum for the mean number of $S$. flava at both infestation treatment levels (Table 2; five aphids: $F=14.63$; $\mathrm{df}=3,72 ; P<0.0001$; ten aphids: $F=9.95$; $\mathrm{df}=3,72 ; P<0.0001)$. A significant interaction between treatment and infestation level $(F=3.03 ; \mathrm{df}=3$, 72; $P<0.035$ ), and treatment and time (evaluation date after infestation; $F=6.13$; $\mathrm{df}=3,72 ; P<0.001)$ was also detected. Results for the mean aphid numbers at 7 and 14 days after infestation were similar between the $S$. graminum and $S$. flava evaluations; however, the relative rank of $\mathrm{K} \times \mathrm{S}$ and Summer was generally exchanged between the two studies. The susceptible sorghum check was consistently among the highest of all grasses for the mean number of $S$. flava at most time points and infestation combinations. At 7 days after aphid introduction, sorghum had significantly higher mean aphid numbers at both the 5-aphid and 10-aphid infestation levels than all switchgrass populations. However, at the 14-day mark, sorghum was not significantly different from Summer for the 5aphid infestation level, or Summer and $\mathrm{K} \times \mathrm{S}$ for the 10-aphid infestation level.
When considering the 5-aphid infestation level, Summer had significantly more $S$. flava than all other switchgrass populations at both the 7-day and 14-day evaluations, with mean aphid numbers of $28.1 \pm 6.1$ and $110.9 \pm 24.5$, respectively. For the 10-aphid infestation level, Summer was not significantly different from $\mathrm{K} \times \mathrm{S}$ at either time point; however, both had significantly greater mean aphid numbers than Kanlow at both the 7-day and 14-day evaluations.

Similar to the results for S. graminum, Kanlow consistently had the lowest mean aphid numbers for $S$. flava as well. Although Kanlow was not significantly different from $\mathrm{K} \times \mathrm{S}$ for the 5-aphid infestation level at either time point, $\mathrm{K} \times \mathrm{S}$ had nearly a twofold higher mean aphid number $( \pm$ SEM) than Kanlow at the 7-day evaluation (11.2 \pm 2.7 and $6.3 \pm 3.2$, respectively), and over a threefold difference at the 14-day mark (33.4 \pm 7.8 and $10.7 \pm 5.3$, respectively). For the 10-aphid infestation level, Kanlow produced significantly fewer aphids at both evaluation dates than Summer and $\mathrm{K} \times \mathrm{S}$. Further, for the 10-aphid infestation level and both evaluation dates, the mean number of aphids for Kanlow was less than one-sixth of those for either of the other populations of switchgrass.

Cumulative Aphid Days Cumulative aphid days were also significant at both 5-aphid and 10-aphid infestation levels with $S$. graminum (Table 3; five aphids: $F=27.19 ; \mathrm{df}=3,72$; $P<0.0001$; ten aphids: $F=17.20$; df $=3,72 ; P<0.0001)$. Generally, CAD for $S$. graminum supported the results for mean aphid numbers at 7 and 14 days after aphid introduction. At both the low and high infestation level, the susceptible sorghum check was significantly higher than any of the switchgrasses with mean CADs ( \pm SEM) of $998.9 \pm 133.4$ and 883.8 \pm 116.5 , respectively. Although not significantly different from Summer at the 10 -aphid infestation level, $\mathrm{K} \times \mathrm{S}$ produced the largest response among the three switchgrass populations, with mean CADs ( \pm SEM) of $614.0 \pm 170.7$ and $412.7 \pm 76.8$ at the 5-aphid and 10-aphid infestation levels, respectively. The mean CAD response for Kanlow was significantly lower than both Summer and $\mathrm{K} \times \mathrm{S}$ at both 5-aphid and 10-aphid 
Table 2 Mean $\pm \mathrm{SEM}^{\mathrm{a}}$ number of $S$. flava among switchgrass populations and sorghum at 7 and 14 days after initial introduction of five or ten aphids

Mean \pm SEM S. flava

\begin{tabular}{|c|c|c|c|c|}
\hline \multirow[b]{2}{*}{ Switchgrass population } & \multicolumn{2}{|c|}{7 days after aphid introduction } & \multicolumn{2}{|c|}{14 days after aphid introduction } \\
\hline & 5-aphid infestation level & 10-aphid infestation level & 5-aphid infestation level & 10-aphid infestation level \\
\hline Kanlow & $6.3 \pm 3.2 \mathrm{a}$ & $7.8 \pm 2.9 \mathrm{a}$ & $10.7 \pm 5.3 \mathrm{a}$ & $15.0 \pm 7.4 \mathrm{a}$ \\
\hline $\mathrm{K} \times \mathrm{S}$ & $11.2 \pm 2.7 \mathrm{a}$ & $48.8 \pm 10.4 b$ & $33.4 \pm 7.8 \mathrm{a}$ & $132.2 \pm 25.4 \mathrm{~b}$ \\
\hline Summer & $28.1 \pm 6.1 b$ & $59.7 \pm 8.9 b$ & $110.9 \pm 24.5 b$ & $200.3 \pm 31.5 b$ \\
\hline Sorghum & $78.2 \pm 6.3 \mathrm{c}$ & $117.6 \pm 13.5 \mathrm{c}$ & $184.6 \pm 15.2 b$ & $170.7 \pm 67.3 b$ \\
\hline
\end{tabular}

${ }^{\mathrm{a}}$ Treatment means within the same column followed by the same letter indicate no significant differences $(P>0.05)$, LSD test

infestation levels. Kanlow had a mean CAD $( \pm$ SEM $)$ of $73.0 \pm$ 31.6 at the 5-aphid infestation level and 70.1 \pm 10.7 at the 10 aphid infestation level. Overall, the mean CADs for Kanlow were less than one-half of those for Summer and $\mathrm{K} \times \mathrm{S}$ at both infestation levels. No significant differences were detected between infestation levels within the switchgrass populations and $\operatorname{sorghum}(F=0.98 ; \mathrm{df}=3,72 ; P=0.41)$.

Significant differences were also detected among the grasses for CADs at both the 5-aphid and 10-aphid infestation levels with $S$. flava (Table 3; five aphids: $F=14.26$; df=3, 72; $P<0.0001$; ten aphids: $F=20.99$; df=3, 72; $P<0.0001)$. Over the duration of the experiment, Summer sustained the highest number of $S$. flava for both the 5-aphid and 10-aphid infestation levels among switchgrasses. For the 5-aphid infestation level, Summer had a CAD $( \pm$ SEM) of $1,694.2 \pm 310.5$, which was significantly higher than any other switchgrass. Summer also had the highest CAD for the 10-aphid infestation level, with a CAD $( \pm$ SEM $)$ of $2,471.7 \pm 268.8$; however, that was not significantly different from $\mathrm{K} \times \mathrm{S}$ within the same level, which had a CAD $( \pm$ SEM) of $1,763.4 \pm 266.2$. Kanlow produced the lowest CADs for both the 5-aphid and 10-aphid infestation levels, with mean CADs $( \pm$ SEM) of $198.5 \pm 86.5$ and $283.9 \pm$ 132.0, respectively. At both infestation levels, CADs for Kanlow were significantly less than both $\mathrm{K} \times \mathrm{S}$ and Summer.
Further, Summer sustained CADs that were more than eightfold higher than the CADs for Kanlow within both infestation levels.

\section{Discussion and Conclusions}

Categories of resistance to aphid pests have been previously documented in accessions of several related grass crops. In wheat, accessions have been identified with each of the three categories of resistance to the Russian wheat aphid, Diuraphis noxia (Kurdjumov), with ten Dn genes controlling resistance to D. noxia [36, 41]. Additionally, Hawley et al. [15] and Miller et al. [21] reported that the $D n 4$ gene displayed antixenosis, antibiosis, and tolerance categories to D. noxia. Importantly, resistance that incorporates two or more categories of resistance is a particularly useful trait that may help delay the development of virulence of new aphid biotypes [11, 41]. In this study, results indicate that Summer and $\mathrm{K} \times \mathrm{S}$ may possess some levels of both antibiosis and tolerance, depending on the aphid species. In general, results indicate the presence of tolerance, and possibly low levels of antibiosis, in Summer to S. graminum; however, for $S$. flava, the data suggest that $\mathrm{K} \times \mathrm{S}$ possesses low levels of antibiosis along with possible low levels of tolerance.

Table 3 Mean $\pm \mathrm{SEM}^{\mathrm{a}}$ cumulative aphid days (CAD) over duration of the study for switchgrass populations and sorghum infested with $S$. graminum and $S$. flava (5- and 10-aphid infest levels)

\begin{tabular}{|c|c|c|c|c|}
\hline \multirow[b]{2}{*}{ Switchgrass population } & \multicolumn{2}{|l|}{ S. graminum } & \multicolumn{2}{|l|}{ S. flava } \\
\hline & 5-aphid infestation level & 10-aphid infestation level & 5-aphid infestation level & 10-aphid infestation level \\
\hline Kanlow & $73.0 \pm 31.6 \mathrm{a}$ & $70.1 \pm 10.7 \mathrm{a}$ & $198.5 \pm 86.5 \mathrm{a}$ & $283.9 \pm 132.0 \mathrm{a}$ \\
\hline Summer & $206.5 \pm 53.5 b$ & $358.8 \pm 123.3 b$ & $1,694.2 \pm 310.5 \mathrm{c}$ & $2,471.7 \pm 268.8 \mathrm{c}$ \\
\hline $\mathrm{K} \times \mathrm{S}$ & $614.0 \pm 170.7 \mathrm{c}$ & $412.7 \pm 76.8 b$ & $604.6 \pm 122.2 b$ & $1,763.4 \pm 266.2 b c$ \\
\hline Sorghum & $998.9 \pm 133.4 d$ & $883.8 \pm 116.5 \mathrm{c}$ & $1,033.1 \pm 33.3 b c$ & $1,229.1 \pm 181.2 b$ \\
\hline
\end{tabular}

${ }^{a}$ Treatment means within the same column followed by the same letter indicate no significant differences $(P>0.05)$, LSD test 
In evaluations for Summer and Kanlow, mean aphid numbers demonstrated that there was an initial increase in aphid numbers followed by a reduction of $S$. graminum numbers over time. However, CAD data demonstrated that Summer plants supported a significantly higher number of $S$. graminum than Kanlow plants throughout the experiment. Altogether, these data suggest that Summer may possess moderate levels of antibiosis to $S$. graminum at lower infestation levels and over time.

The more prominent category of resistance to $S$. graminum within Summer plants appears to be tolerance. Both FPLI values (plant biomass and plant height) indicate the presence of tolerance in Summer to $S$. graminum. Summer had significantly lower FPLI values (based on plant height) than $\mathrm{K} \times \mathrm{S}$ at both infestation levels, and significantly lower FPLI (based on plant biomass) than $\mathrm{K} \times \mathrm{S}$ at the 10 -aphid infestation level. It is particularly noteworthy that Summer plants did not have a significantly different $\mathrm{CAD}$ as compared to $\mathrm{K} \times \mathrm{S}$ plants for the higher infestation level, yet still had significantly lower FPLI values within that infestation level for both indices. Based on these data, tolerance is an important category of resistance to S. graminum for Summer.

Conversely, evaluations for $S$. flava indicated an inverse response between Summer and $\mathrm{K} \times \mathrm{S}$, relative to $S$. graminum. The results for mean aphid numbers and CAD indicated that $\mathrm{K} \times \mathrm{S}$ possessed a moderate level of antibiosis to $S$. flava, relative to Summer. In all parameters for antibiosis, $\mathrm{K} \times \mathrm{S}$ had significantly lower values than Summer at the 5-aphid infestation level. While $\mathrm{K} \times \mathrm{S}$ did have significantly lower FPLI values for both plant biomass and plant height than Summer, significant differences only occurred at the low infestation levels. However, $\mathrm{K} \times \mathrm{S}$ also supported significantly fewer $S$. flava at the low infestation level than Summer, making it difficult to determine if low FPLI values were a result of plant tolerance, or simply less aphid pressure.

Tolerance is generally considered to be particularly beneficial because it places little or no selection pressure on pests to overcome resistance through the development of new virulent biotypes and has little or no indirect negative effects on populations of natural enemies [11-13, 34, 35]. Similarly, tolerance has been a major component of resistance to S. graminum in sorghum, Sorghum bicolor (L.) Moench [12, 44]. Experiments in sorghum hybrids possessing levels of tolerance, showed that photosynthetic rates of resistant sorghum plants were unaffected by $S$. graminum feeding for short durations, while susceptible plants had a significant reduction photosynthetic rates [25]. Nagaraj et al. [25] suggested that the tolerance might be the result of the inability of salivary toxins from $S$. graminum to interact with specific targets in the host plant or longer times needed to cause injury in resistant lines. Further, evaluations for categories of resistance among select sorghum varieties have indicated tolerance as an important component of $S$. graminum resistance based on cumulative insect days [8], chlorophyll content, and photosynthetic rates $[13,25]$, and by tolerance index and proportional dry weight loss [13].

Antibiosis studies evaluated aphid survival and multiplication among the switchgrasses. Significant differences were found in mean aphid numbers at both the 7-day and 14-day evaluations, suggesting that antibiosis is an important category of resistance in switchgrass to both $S$. graminum and $S$. flava. In evaluations for both aphid species, Kanlow consistently had the lowest mean aphid numbers within all time points and infestation levels. Further, mean aphid numbers remained stable for Kanlow across all treatment combinations, regardless of infestation level or date. Kanlow also supported the lowest mean CADs within both infestation levels of $S$. graminum and $S$. flava, among all grasses tested. Collectively, these data demonstrate that Kanlow did have adverse effects on the reproduction and/or survival of both aphid species tested. These results are important and demonstrated that Kanlow possesses multiple-species resistance. Although relatively few studies have evaluated categories of resistance to $S$. flava, similar multi-species resistance was documented in sugarcane, Saccharum spp., to both S. flava and the sugarcane aphid, Melanaphis sacchari (Zehntner), with antibiosis as the primary component of resistance [2].

Multi-species resistance is a particularly important quality; however, it has traditionally been difficult to identify/develop [35]. According to Smith [35], "multiple-species resistance provides many advantages and is much more economically and ecologically valuable because it may result in a greater reduction in the total amount of insecticides applied to the system than reductions resulting from a cultivar with resistance to only one pest, and may be helpful in avoiding the emergence of a secondary pest species as a primary pest". Accordingly, this makes Kanlow an attractive candidate for providing traits that can be used to improve switchgrass germplasm for bioenergy.

Interestingly, while Kanlow had a consistent antibiotic response to both aphid species, Summer had a tolerant response to $S$. graminum and a susceptible response to $S$. flava, whereas, $\mathrm{K} \times \mathrm{S}$ had an inverse response with $S$. graminum and $S$. flava. This indicates multiple resistance mechanisms are present in switchgrass and raises interesting questions about the inheritance of the insect-resistance genes. It is also noteworthy that data for both FPLIs were consistent for both aphid species. While biomass yield is a particularly important parameter for a bioenergy feedstock, indices based on both plant biomass and plant height proved to be effective measures for assessing switchgrass tolerance with consistent responses.

This research provides valuable information and represents the first attempt at categorizing resistance in switchgrass. These studies demonstrated that both antibiosis and tolerance are important categories of resistance in tetraploid switchgrass populations being developed as bioenergy feedstocks. Most 
notably, we demonstrated that Kanlow possesses multiplespecies resistance, with strong antibiotic effects against both $S$. graminum and $S$. flava, while tolerance is an important category of resistance for Summer to $S$. graminum. Collectively, this work provides a foundation for future investigation into insect-resistant switchgrasses to improve our understanding of the antibiotic and tolerant mechanisms involved.

The development of switchgrass lines (or cultivars) with resistance to insects offers potential for proactively managing insect pests of biomass crops with an environmentally and economically sustainable solution. Identifying the categories of resistance is critical for understanding the underlying mechanisms of resistance and improving our knowledge of the plant-insect interactions within this system. Furthermore, identification of the categories and mechanisms of resistance is critical for preserving resistance traits and developing integrated pest management strategies.

Acknowledgments We gratefully acknowledge Z B Mayo for reviewing the manuscript; R. Patrick, S. Harvey, J. Pretorius, and H. Pretorius (University of Nebraska) for technical assistance; and K. P. Vogel for providing the switchgrass germplasm for these studies. This research was supported in part by the USDA - National Institute of Food and Agriculture grant number 2011-67009-30096, and by the USDA-ARS CRIS project 5440-21000-030-00D. The US Department of Agriculture, Agricultural Research Service, is an equal opportunity/affirmative action employer and all agency services are available without discrimination. Mention of commercial products and organizations in this manuscript is solely to provide specific information. It does not constitute endorsement by USDA-ARS over other products and organizations not mentioned.

Open Access This article is distributed under the terms of the Creative Commons Attribution License which permits any use, distribution, and reproduction in any medium, provided the original author(s) and the source are credited.

\section{References}

1. Adamski D, Johnson PJ, Boe AA, Bradshaw JD, Pultyniewicz A (2010) Descriptions of life-stages of Blastobasis repartella (Lepidoptera: Gelechioidea: Coleophoridae: Blastobasinae) and observations on its biology in switchgrass. Zootaxa 2656:41-54

2. Akbar W, Showler AT, Reagan TE, White WH (2010) Categorizing sugarcane cultivar resistance to the sugarcane aphid and yellow sugarcane aphid (Hemiptera: Aphididae). J Econ Entomol 103(4): 1431-1437. doi:10.1603/ec09336

3. Alderson J, Sharp WC (1994) Grass varieties in the United States. Agric. Handb. 170. Washington, DC, USDA, Soil Conserv. Serv.

4. Baxendale FP, Heng-Moss TM, Riordan TP (1999) Blissus occiduus (Hemiptera: Lygaeidae): a chinch bug pest new to buffalograss turf. J Econ Entomol 92(5):1172-1176

5. Bouton J (2008) Improvement of switchgrass as a bioenergy crop. In: Vermerris W (ed) Genetic improvement of bioenergy crops. Springer, pp 295-308.

6. Burd JD, Prasifka JR, Bradshaw JD (2012) Establishment and host effects of cereal aphids on switchgrass (Panicum virgatum L.) cultivars. Southwest Entomol 37(2):115-122

7. Costich DE, Friebe B, Sheehan MJ, Casler MD, Buckler ES (2010) Genome-size variation in switchgrass (Panicum virgatum): flow cytometry and cytology reveal rampant aneuploidy. Plant Genome J 3(3):130-141. doi:10.3835/plantgenome2010.04.0010

8. Dogramaci M, Mayo ZB, Wright R, Reese JC (2007) Categories of resistance, antibiosis and tolerance, to biotype I greenbug (Schizaphis graminum (Rondani) Homoptera: Aphididae) in four sorghum (Sorghum bicolor (L.) Moench. Poales: Gramineae) hybrids. J Kans Entomol Soc 80(3):183-191

9. Dowd PF, Johnson ET (2009) Differential resistance of switchgrass Panicum virgatum L. lines to fall armyworms Spodoptera frugiperda (J. E. Smith). Genet Resour Crop Evol 56(8):1077-1089. doi:10. 1007/s10722-009-9430-6

10. Dowd PF, Sarath G, Mitchell RB, Saathoff AJ, Vogel KP (2012) Insect resistance of a full sib family of tetraploid switchgrass Panicum virgatum $\mathrm{L}$. with varying lignin levels. Genet Resour Crop Evol 60(3):975-984. doi:10.1007/s10722-012-9893-8

11. Ennahli S, Bouhssini ME, Grando S, Anathakrishnan R, Niide T, Starkus L, Starkey S, Smith CM (2009) Comparison of categories of resistance in wheat and barley genotypes against biotype 2 of the Russian wheat aphid, Diuraphis noxia (Kurdjumov). ArthropodPlant Interactions 3(1):45-53. doi:10.1007/s11829-009-9054-y

12. Flinn M, Smith CM, Reese JC, Gill B (2001) Categories of resistance to greenbug (Homoptera: Aphididae) biotype I in Aegilops tauschii germplasm. J Econ Entomol 94(2):558-563. doi:10.1603/00220493-94.2.558

13. Girma M, Kofoid KD, Reese JC (1998) Sorghum germplasm tolerant to greenbug (Homoptera: Aphididae) feeding damage as measured by reduced chlorophyll loss. J Kans Entomol Soc 71(2):108-115

14. Hanafi A, Radcliffe EB, Ragsdale DW (1989) Spread and control of potato leafroll virus in Minnesota. J Econ Entomol 82(4):1201-1206

15. Hawley CJ, Paeirs FB, Randolph TL (2003) Categories of resistance at different growth stages in Halt, a winter wheat resistant to the Russian wheat aphid (Homoptera: Aphididae). J Econ Entomol 96(1):214-219

16. Heng-Moss TM, Baxendale FP, Riordan TP, Foster JE (2002) Evaluation of buffalograss germplasm for resistance to Blissus occiduus (Hemiptera: Lygaeidae). J Econ Entomol 95(5):10541058. doi:10.1603/0022-0493-95.5.1054

17. Heng-Moss TM, Baxendale FP, Riordan TP, Lee K (2003) Chinch bug-resistant buffalograss: an investigation of tolerance, antixenosis, and antibiosis. J Econ Entomol 96(6):1942-1951

18. Hultquist SJ, Vogel KP, Lee DJ, Arumuganathan K, Kaeppler S (1997) DNA content and chloroplast DNA polymorphisms among switchgrasses from remnant midwestern prairies. Crop Sci 37:595598

19. Koch KG, Fithian R, Heng-Moss TM, Bradshaw JD, Sarath G, Spilker C (2014) Evaluation of tetraploid switchgrass (Poales: Poaceae) populations for host suitability and differential resistance to four cereal aphids. J Econ Entomol (In Press).

20. Martinez-Reyna JM, Vogel KP (2008) Heterosis in switchgrass: spaced plants. Crop Sci 48(4):1312-1320. doi:10.2135/ cropsci2007.12.0695

21. Miller HR, Randolph TL, Peairs FB (2003) Categories of resistance at four growth stages in three wheats resistant to the Russian wheat aphid (Homoptera: Aphididae). J Econ Entomol 96(3):673-679. doi: 10.1603/0022-0493-96.3.673

22. Mitchell R, Vogel KP, Sarath G (2008) Managing and enhancing switchgrass as a bioenergy feedstock. Biofuels Bioprod Biorefin 2(6):530-539. doi:10.1002/bbb.106

23. Moore KJ, Moser LE, Vogel KP, Waller SS, Johnson BE, Pedersen JF (1991) Describing and quantifying growth stages of perennial forage grasses. Agron J 83:1073-1077

24. Nabity PD, Zangerl AR, Berenbaum R, DeLucia EH (2011) Bioenergy crops Miscanthus $\times$ giganteus and Panicum virgatum reduce growth and survivorship of Spodoptera frugiperda (Lepidoptera: Noctuidae). J Econ Entomol 104(2):459-464. doi:10. 1603/ec10311 
25. Nagaraj NJ, Reese JC, Kirkham MB, Kofoid K, Campbell LR, Loughin T (2002) Effect of greenbug, Schizaphis graminum (Rondani) (Homoptera: Aphididae), biotype k on chlorophyll content and photosynthetic rate of tolerant and susceptible sorghum hybrids. J Kans Entomol Soc 75(4):299-307

26. Panda N, Heinrichs EA (1983) Levels of tolerance and antibiosis in rice varieties having moderate resistance to the brown planthopper, Nilaparvata lugens (Stål) (Hemiptera: Delphacidae). Environ Entomol 12(4):1204-1214

27. Parrish DJ, Fike JH (2005) The biology and agronomy of switchgrass for biofuels. Crit Rev Plant Sci 24(5-6):423-459. doi:10.1080/ 07352680500316433

28. Prasifka JR, Bradshaw JD, Boe AA, Lee D, Adamski D, Gray ME (2010) Symptoms, distribution and abundance of the stem-boring caterpillar, Blastobasis repartella (Dietz), in switchgrass. BioEnergy Res 3(3):238-242. doi:10.1007/s12155-009-9064-8

29. Prasifka JR, Bradshaw JD, Lee ST, Gray ME (2011) Relative feeding and development of armyworm on switchgrass and corn, and its potential effects on switchgrass grown for biomass. J Econ Entomol 104(5):1561-1567. doi:10.1603/ec10304

30. Prasifka JR, Bradshaw JD, Meagher RL, Nagoshi RN, Steffey KL, Gray ME (2009) Development and feeding of fall armyworm on Miscanthus x giganteus and switchgrass. J Econ Entomol 102(6): 2154-2159

31. Prasifka JR, Buhay JE, Sappington TW, Heaton EA, Bradshaw JD, Gray ME (2011) Stem-boring caterpillars of switchgrass in the midwestern United States. Ann Entomol Soc Am 104(3):507-514. doi: 10.1603/an10183

32. Sarath G, Mitchell RB, Sattler SE, Funnell DL, Pedersen JF (2008) Opportunities and roadblocks in utilizing forages and small grains for liquid fuels. J Ind Microbiol Biotechnol 35:343-354

33. SAS Institute (2008) PROC user's manual. 9.2 edn., Cary, NC.
34. Smith CM (1998) Plant resistance to insects. In: Rechcigl JE, Rechcigl NA (eds) Biological and biotechnological control of insect pests. CRC Press, pp 171-208.

35. Smith CM (2005) Plant resistance to arthropods. Springer, Dordrecht

36. Smith CM, Havlickova H, Starkey S, Gill BS, Holubec V (2004) Identification of Aegilops germplasm with multiple aphid resistance. Euphytica 135:265-273

37. Smith CM, Khan ZR, Pathak MD (1994) Techniques for evaluating insect resistance in crop plants. CRC, Boca Raton

38. Vogel KP (2004) Switchgrass. In: Moser LE, Burson BL, Sollenberger LE (eds) Warm-season (C4) grasses. American Society of Agronomy, Crop Science Society of America, Soil Science Society of America, Madison, pp 561-588

39. Vogel KP, Mitchell RB (2008) Heterosis in switchgrass: biomass yield in swards. Crop Sci 48(6):2159-2164. doi:10.2135/ cropsci2008.02.0117

40. Vogel KP, Sarath G, Saathoff AJ, Mitchell RB (2011) Switchgrass. In: Halford NG, Karp A (eds) Energy crops. The royal society of chemistry, Cambridge, pp 341-380

41. Voothuluru P, Meng J, Khajuria C, Louis J, Zhu L, Starkey S, Wilde GE, Baker CA, Smith CM (2006) Categories and inheritance of resistance to Russian wheat aphid (Homoptera: Aphididae) biotype 2 in a selection from wheat cereal introduction 2401. J Econ Entomol 99(5):1854-1861. doi:10.1603/0022-0493-99.5.1854

42. Wu JT, Heinrichs EA, Medrano FG (1986) Resistance of wild rices, Oryza spp., to the brown planthopper, Nilaparvata lugens (Homoptera: Delphacidae). Environ Entomol 15(3):648-653

43. Young HA, Sarath G, Tobias CM (2012) Karyotype variation is indicative of subgenomic and ecotypic differentiation in switchgrass. BMC Plant Biol 12:117

44. Young WR, Teetes GL (1977) Sorghum entomology. Annu Rev Entomol 22:193-218 